\title{
Where Do Dead Books Go? The Problem of the Soviet Canon Today, on the Example of Johannes Becher's Work in Estonian ${ }^{1}$
}

\author{
KATRE TALVISTE
}

\begin{abstract}
The article describes the conception and editing process of an anthology of Johannes Becher's poems (Unistades täiusest, 1962) in Estonian, and discusses its status in the Soviet and contemporary literary canon. The work on the Becher anthology was led by an already outstanding literary scholar Nigol Andresen and a young poet and translator Ain Kaalep, who later became one of the most prolific and wellknown poetry translators in Estonia. An important part was also played by another poet-translator, August Sang, who already had achieved such a standing in the Estonian literary field. Several other translators contributed to the anthology, making it a common project for intellectuals otherwise very differently positioned vis-à-vis the Soviet political authorities and cultural agendas. Becher's work was strongly promoted by these instances, but his poetry was also read with genuine enthusiasm by the main contributors to the anthology (whose own poetry has certain parallels to some aspects of Becher's), as well as the general public, at that time. After the fall of the Soviet regime it has been forgotten, mostly for the same contextual reasons that once granted its success. The case of his poetry in Estonian explores the question of this new invisibility of now politically irrelevant, but still voluminous and aesthetically intriguing literary works in the post-Soviet canon.
\end{abstract}

Keywords: Nigol Andresen, Ain Kaalep, August Sang, Johannes Becher, translated poetry, literary canon, literature in the Soviet regime, Estonian poetry

DOI: http://dx.doi.org/10.12697/IL.2013.18.1.13

\section{The death of a book}

The study of literature under the Soviet regime is often about breaking down walls and barriers the regime set up, about shedding light into the dark places

1 The article was written with the support of the Estonian Research Council grant no MJD108. 
it insisted on creating. The darkness could be hiding the inner workings of the system (power play behind the events and relations in the literary field, censorship, politics and economy of publishing etc.) or suppressing works and opinions it considered dangerous (forbidden writers from the past and from abroad, works and authors banned from publishing etc.), and today we are working towards revealing the former and liberating the latter. However, a third type of dark place has been born in the process, a place created by the totalitarian regime, but turned dark when the regime's own lights went out. In that place we find numerous authors and works that were promoted in order to support the official ideological and aesthetical programme and failed to achieve either ideological or aesthetical independence from that programme. There have been cases where a book was introduced with only an apparent compatibility with the programme, for already independent or even rebellious reasons. For example, in the afterword to an anthology of Baudelaire's verse poetry (1967), its editor August Sang points out the French communists' contribution to the legal rehabilitation of the poet's six condemned texts (Sang 1967: 130). The interest of Estonian translators in Baudelaire had otherwise been unquestionably pre- and anti-Soviet; in the Soviet Union, Baudelaire had officially been a very unwelcome author. Sang used this convenient reference as a fairly transparent safeguard at a time when a temporarily freer atmosphere made such a publication possible. There have also been cases where an actually compatible text has found appreciation for other merits that have kept it alive in the literary repertoire. For instance, the writer Jaan Kross chose to translate a voluminous selection of Béranger's work both for its potential for secret anti-Soviet interpretation and for a tamely pro-Soviet description that could be given in a lengthy preface (Kross 2003: 210). Kross' own fame, mostly as a novelist, is probably one of the main reasons a new edition of that book, originally published in 1963, was printed in 2006.

But there are also cases where these other merits, although present, have not been sufficient to make a work of literature survive the fall of the regime. Such is the case of Johannes R. Becher, whose translations into Estonian I am about to discuss here. This choice of subject is mostly motivated by the fact that regimes do not create literary works, writers and translators do, and a considerable amount of work of remarkable translators and poets has gone into the creation of Becher's poetry in Estonian. The main result of this work is the 537-page collection of poems Unistades täiusest (Dreaming of Perfection, after one of Becher's own titles - Vollendung träumend), published in 1962 and by now all but dead for the public. As determined by the librarians of the Tartu Public Library on 12 December 2012, the book has been checked out five times since the library joined the national digital library network, that is since 2000 
(Reial, Tamme 2002). The Google search engine manages to find various sources (from school papers to academic texts) where Becher's name illustrates German Expressionism, on a few occasions also as a prominent example of it in Estonian, thanks to the 1962 anthology (Olesk 2010, Hennoste 2012). The fact that the anthology has had a life at some point, is still shown by a few references, of which the most powerful one is a passage from the beginning of Viivi Luik's novel Seitsmes rahukevad (The Seventh Spring of Peace, 1985), where the narrator, reliving one of her post-war childhood's fears associates it with two verses from one of Becher's poems (Luik 1985: 4) - the first two of the poem "Baudelaire". Also, in October 1972, a half-hour radio reading of Becher's poetry and essays had been recorded and is now available online (Eesti Raadio 1972). Becher's poetry has obviously been read and has left a certain impression on even considerable literary minds, but if the book's status in library catalogues and the reactions of readers from newer generations can be believed, it has stopped attracting new readers. Some books are probably meant to die with the contexts that produced them, but there still remains the question of what else dies along with them, and if there is something that could or should survive, what it is and how are we to access it, if it is contained in a dead book. Becher's Unistades täiusest will serve here as a tool for exploring this problematics, which is itself a lot broader than this particular case study, concerning other texts, authors and translators than those involved here.

\section{The birth of a book}

Becher's important status in the Soviet literary field is understandable: a lifelong rebel turned active communist in the 1920s, a fervent speaker against the Nazi regime from his exile in the Soviet Union from 1935 to 1945, and later high functionary in East Germany, he had a perfectly acceptable profile. On that status level, once it was achieved, even the youthful "indiscretions" of serious (self)destructive behaviour and Expressionist poetics could be forgiven or explained away as the first, clumsy attempts at an anti-bourgeois rebellion. It is from that period during and after the First World War that the first Estonian translations of Becher's poetry date. His early works interested Estonian poets and translators in the context of German Expressionism, their most important source of inspiration in search of an adequate poetic response to the war and the painful experiences it brought about. The first registered poem to appear in Estonian periodicals is "Torm" (original title "Sturm"), translated by Johannes Semper and published in 1919 (Becher 1919). This text is reprinted in the 1962 
anthology with minor orthographical corrections ${ }^{2}$. Another important publication of Becher's poems (5 texts) was the anthology Valik saksa uuemast lüürikast (A Selection of Contemporay German Lyrical Poetry, 1920) established and translated by the poetess Marie Under (Becher 1920). A few more texts were published in various periodicals in the 1920s and 1930s. One of them (Becher 1928) was translated, or rather adapted, by Nigol Andresen (1899-1985), later editor of the 1962 anthology. The anthology contains this particular poem ("Die Arbeitslosen") in Ain Kaalep's translation.

The author of the earliest translation, Johannes Semper (1892-1970), has an eerily parallel destiny to that of Becher. After his first, but quite substantial, contributions to literary criticism and comparative literary study already before the First World War and his essentially neosymbolist poetry debut in 1917, Semper turned to Expressionist poetics and took the position of a leftwing intellectual involved in cultural politics and social issues. Over the next decade, Semper abandoned his initial militant stance and concentrated mostly on literary and academic activities, rising to the post of editor-in-chief of the principal literary magazine Looming and teaching at the University of Tartu. However, he never abandoned his original socialist views and became an active participant in the creation of the Soviet regime in Estonia, once the coup of 1940 had taken place (he was the minister of education from 1940 to 1948, and the author of the lyrics of the anthem of the Estonian SSR). Having organised the Estonian cultural activities behind the Soviet lines during the war, he returned to Estonia, where he was chairman of the Writers' Union until 1950, at which time the Stalinist regime turned the repressions against its early supporters and leading intellectuals, and Semper, like many others, was expelled from the Union and stripped of all other forms of institutional status and support. As the rehabilitations started after Stalin's death in 1953, his period of disgrace (including publishing restrictions) lasted only a few years, later on he returned to mostly literary activity.

Johannes Becher's biography contains even some identical details (he, too, did a considerable amount of editorial work; he was the minister of culture of the DDR from 1954 to 1958, and he wrote the lyrics for the DDR anthem). Although the two authors also followed very different paths in some matters, their reception has been thoroughly influenced by their political views and activities: both Becher (see Rohrwasser 1980: 41) and Semper have been

2 In his translations from French (Verhaeren, Baudelaire), Semper made considerable changes in the versions published in the 1950s and 1960s. It is hard to say, at this point, whether he found rewriting Becher less interesting in his later years or less necessary, being already satisfied with the initial result. 
considered as traitors or collaborators by critics representing different ideological positions. Their poetics also show clear parallels, which is not entirely surprising in two contemporary authors. The Expressionist Semper's fascination with the Expressionist Becher around 1920 is understandable. But if Expressionism then was the road that led several Estonian poets to Becher, later Becher himself became an important tool for rehabilitating Expressionism, one of the many "formalist" enemy poetics defined by the Stalinist criticism. Rehabilitating Expressionism as an accepted object of study and translation was initiated by the critic Nigol Andresen, a casual translator of Becher himself in his youth and later specialist in German Expressionist poetry (Olesk 2007: 105). His 1962 Becher anthology is among the most canonic examples and certainly the most voluminous one.

Although Becher had not fared too well in the Soviet Union during the worst years of Stalinist repressions, he had been known there well before 1933 as one of the most prominent authors in many anthologies of foreign poetry and, therefore, an author often studied by Soviet critics (Weiss 1971: 184, 194). In later years, his attempts at creating a theory of poetry compatible with Socialist Realism found even more favour in the eyes of Soviet criticism; that motive is also used by Nigol Andresen in proving Becher's importance and justifying the need for an anthology (Andresen 1958; Andresen 1962: 526). The precise trigger event in the creation of the anthology seems to have been Becher's death in 1958: not only did it inspire a number of translations in periodicals, but Andresen's manuscripts and correspondence kept in the Estonian Cultural History Archives show that by the end of 1958 (Becher died in October) he had delineated an initial version (later to grow to an almost double volume) of the anthology together with its main translator Ain Kaalep (b. 1926), who had already published five poems in the magazine Looming (Becher 1958). This project constituted the beginning of a long and close relationship between Andresen and Kaalep as colleagues, brought together by their shared interest in German poetry and nourished by their shared intellectual values as well as Andresen's general supportive attitude towards younger colleagues (Olesk 2007: 105).

In the Becher project, the collegial aspect seems to be of some relevance. Most of the contributors, including Andresen himself, were victims of the last Stalinist repressions in the early 1950s, no matter how pro- or anti-Soviet they had been in their former activities, how high their rank in the Soviet administration or how humble their professional and social situation. In this respect, the ten translators of the Becher anthology represent the full variety of positions taken by the Estonian intellectuals (or imposed upon them) under Soviet occupation. The Becher project was certainly not their first chance to return to 
creative activity and to being published - it was launched several years after the first signs of post-Stalinist thaw in the mid-1950s. However, the situation still warranted caution. Creating a safe and, considering the Soviet remuneration policy, rather profitable project for several appreciated colleagues struggling to find some stability after more than a decade of upheavals and persecution, must have been one goal in Andresen's mind, although not a clearly documented one . $^{3}$.

The documents do reveal, however, that he also must have had an authentic goal of creating a solid collection of poetry he obviously appreciated. Although he is the only editor named in the impressum, he collaborated closely with the two main translators, Ain Kaalep and August Sang (1914-1969). Between the three of them, they have left behind a rather large collection of drafts, both for texts and for the structure of the book. Finding the optimal solution for the latter, choosing, assigning and reassigning poems to the translators, comparing parallel translations ${ }^{4}$, approving, discarding and replacing submitted work was a long process that went through many stages and involved close reading of Becher's considerable poetic work on one the hand and practical coordination of the project on the other. At its definitive, published stage, the bulk of the Becher anthology is made up of Kaalep's and Sang's translations: respectively 115 and 70 texts. One of Kaalep's translations is a collaboration with Jaan Kross, who, together with that one, has contributed 19 poems. Debora Vaarandi's part is of comparable importance: 24 poems. Other translators have contributed under ten texts each (Johannes Semper - 6, Artur Alliksaar - 4, Rein Sepp - 4, Harald Rajamets - 2, Eduard Kook - 2, Paul Viiding - 1).

Kaalep's and Andresen's correspondence from autumn 1958 till autumn 1962 shows a constant reflection upon the Becher project and Becher's work, even when sometimes pauses in the actual work come up or they concentrate on other matters in their letters. The structure of the book was a central and meaningful problem, as demonstrated by many drafts kept by Andresen (see

3 The fact that Artur Alliksaar (1923-1966), a remarkable poet whose anti-Soviet ways caused him to become virtually unable to publish in his lifetime, was included among the translators (together with several others who had fought against Soviet occupation, had been imprisoned and/or deported) is one indication of such consideration. Ain Kaalep's and August Sang's letters to Andresen from May 1962 (Sang to Andresen, 7 May 1962; Kaalep to Andresen, 10 May 1962) reveal that Alliksaar's name in the book actually stopped the publishing process for several months, however, by early July the situation had been happily resolved (Kaalep to Andresen, 2 July 1962).

4 The poem "Barcelona", of which August Sang has had translations from Ain Kaalep and Jaan Kross (see Sang's materials for the Becher anthology), has even been published in the anthology in a combined version (Becher 1962: 216-217). 
Andresen's materials for the Becher anthology), Kaalep's constant return to the subject (see letters to Andresen from 8 January 1959 and 4 December 1961), meetings held to discuss it (see Kaalep's letter to Andresen from 3 February 1962) and efforts made in winter 1961/1962 to obtain, for comparison, the latest German edition of Becher's poetry (Vom Verfall zum Triumph), although by that time Andresen and Kaalep had already started to seriously worry about deadlines. In January 1959, Andresen had envisioned an anthology of about 100 poems, up to 3500 verses in total, which estimate he has later crossed out and replaced by 5000 (Andresen 1959), which corresponds better to the actual volume (246 poems). Kaalep's letters to him give an idea about how this expanding happened through constant discovery of new inspiring texts. "Dear comrade Andresen! The problem with Becher is that one can drown in him," Kaalep wrote to Andresen on 7 July 1961. Andresen obviously experienced the effect himself: having foreseen a simple two-page fact list about Becher's life and work (Andresen 1959) to accompany the book, he ended up writing a much longer afterword (Andresen 1962). Thinking back, Kaalep even mildly regrets having gotten "carried away" in this fashion and believes the Becher anthology to have twice the volume it would have needed to have (Kaalep 2013).

Unistades täiusest is clearly a product of intense and authentic creative work and reflection, mainly carried out by three outstanding men of letters, with contributions from other remarkable poets and some eminent translators. Andresen and his colleagues have made use of several efficient strategies of introducing foreign literature into a highly controlled, restricted and censored literary environment. But they have clearly been motivated by literary merits of the book, not only by a wish to outsmart the system and keep themselves occupied with something moderately acceptable. What, then, are these merits, if any can still be found; in other words: in what way does Becher let our poets express matters which could be considered as truly compatible with their own poetics and values?

\section{The life of a book}

The Becher anthology consists of eleven cycles (two of them divided into subcycles). The first six show the evolution of Becher's poetry from the early years till 1951. Three thematic cycles follow, which contain poems from several decades (from mid-twenties to early fifties for the first two, early thirties to late forties for the last) and explore meaningful experiences of love, art and environment (nature or urban space). The tenth cycle contains poems about the Soviet Union and the last, eleventh, represents Becher's last years. The general 
development is that of a lyrical subject first full of youthful dramatism and grandiloquence in expressing his horror at war, violence and social injustice as well as his hope and determination to build a better future. This position does not change much over time, but finds more discreet ways of expression and a greater attention to actual details of social and human reality instead of the Expressionist tropes of horror and misery. Parallel to the development of Becher's political convictions, his leaving Germany and settling in Moscow, nostalgia for the lost homeland (doubly lost due to his own exile and the establishment of the Nazi regime) and Soviet subject matter appear, later to be completed with images of Germany ravaged, morally and materially, by yet another war. However, Becher's lament for his country and culture is always counterbalanced by his conviction that a better world could be built which he obviously associates with communism.

The communist aspect aside, this general attitude is also characteristic of his two principal Estonian translators. Sang and Kaalep express similar basic values, and in some respects, their way of expressing them coincides with Becher's. The patterns of poetical or ethical parallelism between two lyrical worlds - the translator's and the translated poet's - can be traced at several levels. In Sang's case, the most interesting shared characteristic with Becher is a certain type of ethical reflection, evolving through many poems. The parallels are not only static resemblances between certain images, tropes or thoughts expressed; they appear in the dynamics of thought and poetics. In several poems, the two authors move through similar stages of exhaustion, frustration and (self-)doubt conquered by a conscious effort of faith and hope for a new beginning, almost in spite of themselves and certainly in spite of the knowledge that other ways of life might be easier. These other, ethically unacceptable ways often find concretisation and portraying in various rather grotesque characters, giving to many poems in both poets' work a distinctly lyro-dramatic shape. If the conflict of values does not take such a clear dramatic form, their texts still often remain dialectic in structure, letting the negative instance disqualify itself by voicing its position. Sometimes the negative instance can be found within the lyrical subject itself, in its unfailing willingness to keep up with the demands of their envisioned future, smiling (in Sang's case) or sometimes frowning (in Becher's) at their former or even present selves.

While their historical and personal experiences and choices were fundamentally different in many ways, both Sang and Becher arrive at a point where poetry obviously becomes a means of working through their comparable experience of a great war and a great upheaval of social environment, of unspeakable violence and terror and of an overwhelming feeling of uncertainty that ensued. This uncertainty had many levels, of which perhaps the hardest to deal with, at 
least according to Sang's and Becher's lyrical subject, was the ambiguity of the subject's own choices in these chaotic and violent times. One shared core element of their postwar poetry is the very difficulty of choosing one's way in the midst of great chaos and terror, and the impossibility to determine one's own responsibility in the outcome of the events - a sort of survivor's guilt, perhaps best illustrated by parallelisms between Sang's poem "Tagasivaade" ("A Look Back", Sang 1963: 35-37) and Becher's “Tuhk minu rinda põletab” (Becher 1962: 286, original title "Die Asche brennt auf meiner Brust") to which Sang has lent some key vocabulary almost identical to the one he has used in his own text that follows the same line of reasoning and imagery. However, while Becher always seems essentially serious and tragic in reflecting upon his experiences, Sang very rarely looses his discreet irony, often good-natured and directed also at himself, sometimes sharp and satirical.

In this respect, Kaalep and Sang are quite like-minded: neither has Becher's capacity for irrevocable despair, and if there is one element characteristic of them both and harder to find in their translations of Becher, it is their playfulness and the genuine joy that tends to balance out the darker aspects of life. Still, Kaalep has translated many moments where Becher comes to his closest to playing, either with lyrical roles (Becher 1962: 93-94; Becher 1962: 204205), the structure of the text (Becher 1962: 126-127) or metapoetical figures (Becher 1962: 162; Becher 1962: 471). Kaalep has also contributed a few texts that reveal sensual aspects of Becher's poetry (Becher 1962: 29; Becher 1962: 176). The aspect in which Becher's and Kaalep's voices seem to have a more than fleeting similarity is their easy capacity to find kindred spirits in history, empathy and solidarity towards other poets, artists, musicians or even fictional characters. Kaalep has translated a number of Becher's tributes to artists or to works of art, and even though other translators have contributed as well, his own works shows a natural tendency towards such a poetic dialogue with cultural and literary heritage, examples of it can be found already in his first two collections of poetry, Aomaastikud (Dawn Landscapes) and Samarkandi vihik (Booklet of Samarkand), published in the same year as the Becher anthology.

As far as the form is concerned, Sang lends his seemingly effortless rhythms and his gift for shaping a perfectly natural-sounding speech into sometimes long and complex poems, to his translations of Becher as well as many other foreign poets. Kaalep as an original poet is quite different from Sang: while respecting the natural prosody and structures of the language, he is one of the most dedicated and rigorous versification enthusiasts in the history of Estonian poetry. The enthusiasm means not only scrupulous attention to all phonetic and metric nuances in the chosen form, but also an interest for a large variety of forms originating from all ages of the Western literary tradition and numerous 
other verse traditions in the world, both written and oral. In Becher's translations, these preferences do not stand out as clearly, since, as translators, both poets are very capable of following the original. Becher's rather varied form thus brings Sang a bit further away from his own dominant poetics and gives Kaalep free hands to explore different types of verse and strophe (which he, in his own poetry, does even more widely).

Finally, all three poets find some important common ground in the image they have of a poet's vocation. The figure of a socially responsible poet, one that considers himself as one craftsman among many others who bring their various competences to the joint effort of bettering the world, appears in the work of all three. Becher's self-image is a bit more heroic, and logically so: if the darkness is as overwhelming as he often perceives it, then optimism could not stem from anything else than heroism. In Kaalep's and Sang's more balanced nature, it seems more like a foundation almost impossible to entirely overwhelm. But even if Becher's rhetoric has a more solemn ring, they all consider a poet as a part of community, responsible for its well-being like any other member of this community, able to make reasonable contributions, especially by seeing beauty in all aspects of human life and practices.

Creating an Estonian Becher cannot therefore be explained away in terms of contextual reasons and survival tactics only. There are values expressed in Becher's book and in translators' own contribution to it that could be doubted only if we were prepared to extend the same doubt to these poets' own work, to some of its most prominent and omnipresent motives, and the question would arise as to how much doubt a reader, even an academically minded one, can afford before his or her own integrity is compromised. With integrity, however, close reading may reveal affinities between authors that are quite independent from their actual life choices or political positions. Poetry can explore shared human experiences, concerns and ways of expression that, albeit furtively, go beyond social or political causes people embrace and many incompatibilities that stand between them. While we assure ourselves that the real meanings were hidden "between the lines" in the Soviet period, and are now busy extracting them by various means, the lines themselves should not be forgotten in the process. Whatever regime-imposed features the Becher anthology may have, it has clearly offered ways to express genuine concerns and hone genuine poetical capacities, and other books of same background and fate may share this quality. This is not necessarily reason enough for any serious attempts to resuscitate them all for general reading, but it seems fair to visit their graves every now and then. 
TALVISTE

\author{
Katre Talviste \\ katre.talviste@ut.ee \\ Tartu Ülikool \\ Kultuuriteaduste ja Kunstide Instituut \\ Ülikooli 16 \\ 51014 Tartu \\ EESTI
}

\title{
References
}

Andresen, N. 1958. Johannes R. Becher eesti lugejate ees. - Looming, 10, 1601-1606.

Andresen, N. 1959. Johannes R. Becheri luulevalimiku kava. - Johannes R. Becher, „Unistades täiusest”. Koostamise materjale. EKLA, f311, m 69:4.

Andresen, N. 1962. Johannes R. Becher. - J. R. Becher, Unistades täiusest. Tallinn: Eesti Riiklik Kirjastus, 521-528.

Andresen, N. Johannes R. Becher, „Unistades täiusest”. Koostamise materjale. [Materials for the Becher anthology.] EKLA, f 311, m 69:4.

Becher, J. 1919. Torm. - Odamees, 4, 3-6.

Becher, J. 1920. Sissejuhatus; Ühele noormehele; Lokomotiivid; Kaebe ja küsimus; Palve nelipühil 1917. - Valik saksa uuemast lü̈̈rikast. Tallinn: Auringo, 158-172.

Becher, J. 1928. Töötatöölised. - Rünnak, 3, 73-74.

Becher, J. 1958. Pilt mälestuseks; Ühe koolja käele; Mälestusi ühest luuletajast; Ühine tee sinuga; Ulmadest. - Looming, 10, 1527-1529.

Becher, J. R. 1962. Unistades täiusest. Tallinn: Eesti Riiklik Kirjastus.

Eesti Raadio 1972. Keskööprogrammi luulekava. Johannes Becheri luulet ja mõtteid luulest. - http://arhiiv.err.ee/, RMARH-52297 (27.01.2013).

Hennoste, T. 2012. Hüpped modernismi poole II. 20. sajandi eesti kirjandusteadus Euroopa kirjandusteaduse taustal. 25. loeng: Stalinismist perestroikani IV: modernismi ümber. - Vikerkaar, 3, www.vikerkaar.ee (17.12.2012).

Kaalep, A. Ükssada kolm kirja Nigol Andresenile. 20.IX 1958-6.XI 1964. [Letters to Nigol Andresen.] EKLA, f 311, m 11:1.

Kaalep, A. 2013. Interview given to K. Gielen and K. Talviste. Elva, 03.05.

Kross, J. 2003. Tõlkimine - kas kunst? kas teooria? - Omaeluloolisus ja alltekst. 1998. a. Tartu Ülikooli filosoofiateaduskonna vabade kunstide professorina peetud loengud. Tallinn: Eesti Keele Sihtasutus, 186-211.

Luik, V. 1985. Seitsmes rahukevad. Tallinn: Eesti Raamat.

Olesk, P. 2010. Maailmakirjandus Pärnust. - Pärnu Postimees, 16.12.

Olesk, S. 2007. Kaks vaimukaaslast eri aegadest. Valik Ain Kaalepi ja Nigol Andreseni kirjavahetusest aastatel 1965-1975. - Tuna, 4, 103-122.

Reial, M., Tamme, A. 2002. Infotehnoloogiline areng. Raamatukogud infoühiskonna kommunikatsioonisüsteemis. - http://www.elnet.ee/elnet/Dok_ITareng_p.html $(17.12 .2012)$ 
Where Do Dead Books Go?

Rohrwasser, M. 1980. Der Weg nach oben. Politiken des Schreibens. Basel / Frankfurt: Stroemfeld / Roter Stern.

Sang, A. 1963. Võileib suudlusega. Tallinn: Eesti Riiklik Kirjastus.

Sang, A. 1967. Koostajalt. - Ch. Baudelaire, Kurja lilled. Tallinn: Perioodika, 129-130.

Sang, A. Kaks kirja Nigol Andresenile. 25.II 1959-7.V 1962. [Letters to Nigol Andresen.] EKLA, f 311, m 24:16.

Sang, A. J. Becher'i luulevalimiku materjalid: luuletuste tôlked, bibliograafia + trükimaterjal. [Materials for the Becher anthology.] EKLA, f 300, m 22:4.

Weiss, E. 1971. Johannes R. Becher und die sowjetische Literarturentwicklung (19171933). Berlin: Akademie-Verlag. 